\title{
Contribution of Insurance Sector to Growth and Development of the Indian Economy
}

\author{
${ }^{1}$ Dr. M.Subba Rao, ${ }^{2}$ R. Srinivasulu \\ ${ }^{I}$ M.Com, M.Phil, Ph.D Principal Sri Balaji P.G College (MBA) Anantapur - 515002 Andhra Pradesh - India \\ ${ }^{2}$ M.Com, M.B.A Research Scholar Department of Commerce S.K University - Anantapur Andhra Pradesh - \\ India
}

\begin{abstract}
For economic development, investment are necessary, investments are made out of savings.
Insurance Company is a major instrument for the mobilization of savings of people particularly from the middle and lower income groups. These savings are channelized into investment for economic growth. Insurance serves a number of valuable economic functions that are largely distinct from other types of financial intermediaries.

According to the official estimates, Indian economy is expected to grow at $7.6 \%(+/-0.25 \%)$ in the fiscal year 2012-2013. However, leading financial organizations and economic think-tanks expect Indian economy to grow slower than official projections. The economy of India is the tenth-largest in the world by nominal GDP and the third largest by purchasing power parity (PPP). The country is one of the G-20 major economies and a member of BRICS. On a per capita income basis, India ranked 140th by nominal GDP and 129th by GDP (PPP) in 2011, according to the IMF.

Fortunately, in the past few years, several interesting lines of research have begun to map the specific contributions of insurance to the economic growth process as well as to the well-being of the poor. The evidence suggests that insurance contributes materially to economic growth by improving the investment climate and promoting a more efficient mix of activities than would be undertaken in the absence of risk management instruments. This contribution is magnified by the complementary development of banking and other financial systems.

Empirical studies suggest that nonlife insurance contributes to growth in countries at many different levels of development. Life insurance makes a substantial contribution to growth mostly in wealthier countries, since life insurance is typically a smaller part of the total insurance market in low income countries. Of course, even if the data did not support a strong causal role for insurance as an engine of overall aggregate growth of the Indian economy.
\end{abstract}

\section{Introduction}

The Gross Domestic Product (GDP) in India expanded 0.60 percent in the third quarter of 2012 over the previous quarter. GDP Growth Rate in India is reported by the Organization for Economic Cooperation and Development (OECD). Historically, from 1996 until 2012, India GDP Growth Rate averaged 1.6 Percent reaching an all time high of 6.1 Percent in March of 2010 and a record low of -1.5 Percent in March of 2004. In India, the growth rate in GDP measures the change in the seasonally adjusted value of the goods and services produced by the Indian economy during the quarter India is the world's tenth largest economy and the second most populous. The most important and the fastest growing sector of Indian economy are services. Trade, hotels, transport and communication; financing, insurance, real estate and business services and community, social and personal services account for more than 60 percent of GDP. Agriculture, forestry and fishing constitute around 12 percent of the output, but employs more than 50 percent of the labor force. Manufacturing accounts for 15 percent of GDP, construction for another 8 percent and mining, quarrying, electricity, gas and water supply for the remaining 5 percent.

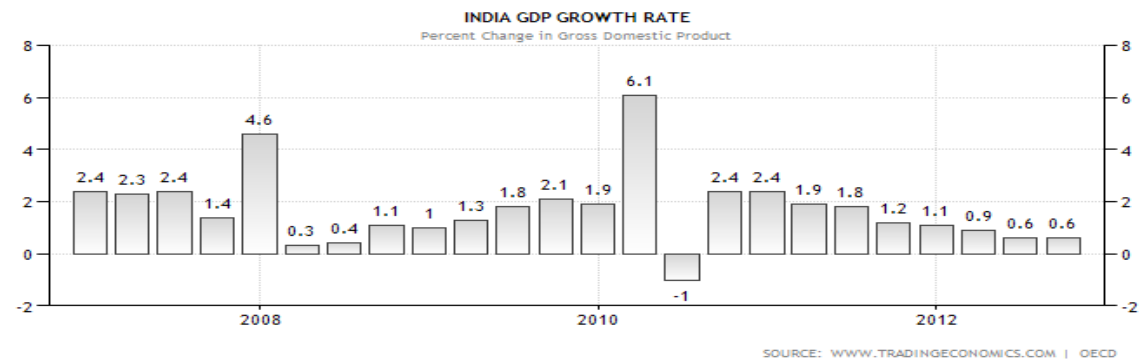

India's GDP Growth Slows to 5.3 Percent in Q3

Ministry of Statistics and Programme Implementation 12/11/2012 4:51:41 PM 


\section{India's economy has expanded by just 0.6 over the previous quarter and 5.3 percent over the previous year in the third quarter.}

The economic activities which registered significant growth in the fourth quarter year-over-year are construction at 6.7 per cent, trade, hotels, transport and communication at 5.5 per cent, financing, insurance, real estate and business services at 9.4 per cent, and community, social and personal services at 7.5 per cent. The growth rates in agriculture, forestry \& fishing is estimated at 1.2 per cent, mining and quarrying at 1.9 per cent, manufacturing at 0.8 per cent, electricity, gas and water supply at 3.4 per cent in this period.

According to the latest estimates available on the Index of Industrial Production (IIP), the index of mining, manufacturing and electricity, registered growth rates of 1.8 per cent, 0.2 per cent and 2.8 per cent, respectively in Q3 2012, as compared to the growth rates of (-) 4.1 per cent, 3.4 per cent and 10.5 per cent in these industries in Q3 2011. The key indicators of construction sector, namely, cement and consumption of finished steel registered growth rates of 5.1 per cent and 2.3 per cent, respectively.

Exports have slowed down as a result of Europe's sovereign debt crisis that has slowed exports. Investment has declined as the central bank has maintained high interest rates to curb inflationary pressures.

Amid fears of a credit downgrade, the government's poor fiscal position has not allowed for expansive fiscal policy to stimulate the economy towards the target growth rate.

\section{The Slowing Down Of Indian Economy}

Now the time has change, there is not a recession kind of situation currently but definitely the problems are there as the growth of Indian economy has lost its way Government of India needs to refresh its policies in order to add a boost to exhausting Indian economy so that GDP rate comes back to the track.

India's growth to slow this year due to high inflation, says Organization for Economic Cooperation and Development (OECD) Projects 2012. The Organization for Economic Cooperation and Development projected India's economic growth rate to slow down to 7.1 per cent in 2012 against 7.3 per cent in 2011 due to high inflation that leaves limited space for the Reserve Bank of India (RBI) to manoeuvre. Economic growth would, however, expand by 7.7 per cent in 2013, OECD said.

It should be noted that these growth figures are not exactly comparable with India's official figures, as the country takes GDP at factor cost (exclusive of indirect taxes), while OECD cal In its latest economic outlook, OECD said further action on the monetary policy front would be constrained by inflationary pressures. India's wholesale price inflation rose to 7.23 per cent in April from 6.89 per cent in the previous month.

However, food inflation entered double digits, even as the overall inflation, based on consumer prices, has already risen to double digits at 10.36 per cent in April from 9.47 per cent in March.

Inflation remains relatively high, OECD said, adding expected increase in regulated prices of some oil-related products will add to price pressures which will continue to weigh on household consumption. "This in turn will make the climate for investment less favourable. As a result, growth is expected to remain subdued through much of the year," the report said.

According to Reuters, the report also said continued government policy uncertainty could erode the country's long-term growth prospects. In the medium term, India plans to target nine per cent growth rate a year on an average for a five-year period starting this financial year.

The report also said the government's fiscal consolidation plans this year would help reduce inflation and narrow the current account deficit. It, however, said there would be spending pressures on subsidies. The government has targeted to bring down subsidies to 1.9 per cent of GDP this financial year.

Overall fiscal deficit is targeted to reduce to 5.1 per cent of GDP in the current financial year against 5.9 per cent in 2011-12. The current account deficit stood at a record four per cent of GDP in the first nine months of 2011-12.

The global financial crisis of 2008 pulled down India's growth rate to 6.7 per cent in 2008-09. India has projected a growth rate of 7.6 per cent in 2012-13, up from 6.9 per cent recorded in 2011-12.

Economic growth in India has slowed due to a slump in manufacturing and investment spending. Meanwhile, the softening of external demand and rising imports have widened the current account deficit (CAD). OECD said the global economy was also gaining momentum, but the recovery is fragile.

GDP growth across OECD is projected to get slower from 1.8 per cent in 2011 to 1.6 per cent in 2012, before recovering to 2.2 per cent in 2013 .

"With slow growth, high unemployment and limited room for manoeuvre regarding macroeconomic policy space, structural reforms are the short-run remedy to spur growth and boost confidence," OECD Secretary-General Angel Gurria said. 


\section{Reasons For Slowing Down Of Indian Economy}

The speed and depth of global integration accelerated sharply in the first decade of the 21st century. The average international trade (exports+imports) ratio which for the period 1992/3-94/95 stood at 19 per cent rose to 27 per cent by 2000/01-02/03. However by 2008/9-2010/11 this ratio had shot up to 48 per cent. But in this phase of rapid integration import elasticities - of both total imports as well as non-oil imports - have more than doubled. As a result, even as GDP growth has decelerated, goods export growth has slowed faster than both total goods import and non-oil import growth, resulting in a widening current account deficit, given that service sector exports growth dropped off as well.

\section{- Delay in policy implementation by Government of India -}

Many policies and bills are awaiting from a long time to get approved even the proposal of Allowing $51 \%$ FDI in retailing is still hanging in middle from a long time. GOI should understand that policies applied during financial reforms of 1991 had worked brilliantly for India, but now the country needs new sets of policies and reforms to boost the slowing economy. The lackluster behavior of Indian Govt. is damaging the image of India globally and sending an impression to the world that Govt. is not really concerned for the growth of Indian economy.

\section{- 2. Due to high inflation, interest rates also remains high for industry -}

Inflation is a serious problem for Indian economy from many decades and honestly there isn't any solution available for it as high inflation is mainly because of high fuel prices. As we all know we have to import more than $80 \%$ of our demand and sell it to consumers here, at high prices thus increasing inflation, so in order to control the inflation RBI increases interest rates due to which Industry get loans from banks at higher interest rates only as a result Companies reduces investment in India which makes the whole economic cycle of the country slow.

\section{- 3. Tragic global economic scenario affects India too -}

There is no doubt that Indian economy is passing through the tough phase due to our internal problems but the economic environment globally is also not very promising instead the current problems of European countries have affected Indian economy too as in the age of globalization outer factors are also important for any country's economy to grow.

\section{- 4. The increasing corruption and scams in the country -}

Corruption existed in India from very starting but in recent times it has grown to a new level that now it is cramping the growth of the Indian economy. Recent charges of corruption against Government of India has disturb the sentiments of investors now they don't see India as a safe place to invest which has affected the foreign investment in India.

\section{Introduction To Insurance Industry}

The economic reforms initiated in the early 90s paved the way for the growth and opening up of the financial sector, which led to a sustained period of economic growth. The insurance industry was opened up for private players in 2000 , and has seen tremendous growth over the past decade with the entry of global insurance majors. India is fast emerging as one of the world's most dynamic insurance markets with significant untapped potential.

The insurance sector plays a critical role in a country's economic development. It acts as mobilize of savings, a financial intermediary, a promoter of investment activities, a stabilizer of financial markets and a risk manager. The life insurance sector plays an important role in providing risk cover, investment and tax planning for individuals; the non-life insurance industry provides a risk cover for assets.

Health insurance and pension systems are fundamental to protecting individuals against the hazards of life, and India, as the second-most populous nation in the world, offers significant potential for that type of cover. Furthermore, fire and liability insurance are essential for corporations to safeguard infrastructure projects and investment risks. Private insurance systems complement social security systems and add value by matching risk with price.

\section{Evolution of the industry}

The growing demand for insurance around the world continues to have a positive effect on the insurance industry across all economies. India, being one of the fastest-growing economies (even in the current global economic slowdown), has exhibited a significant increase in its GDP, and an even larger increase in its GDP per capita and disposable income. Increasing disposable income, coupled with the high potential demand for insurance offerings, has opened many doors for both domestic and foreign insurers. 
In India, the Ministry of Finance is responsible for enacting and implementing legislations for the insurance sector with the Insurance Regulatory and Development Authority (IRDA) entitled with the regulatory and developmental role. The government also owns the majority share in some major companies in both life and non-life insurance segments.

Both the life and non-life insurance sectors in India, which were nationalized in the 1950s and 1960s, respectively, were liberalized in the 1990s. Since the formation of IRDA and the opening up of the insurance sector to private players in 2000 , the Indian insurance sector has witnessed rapid growth.

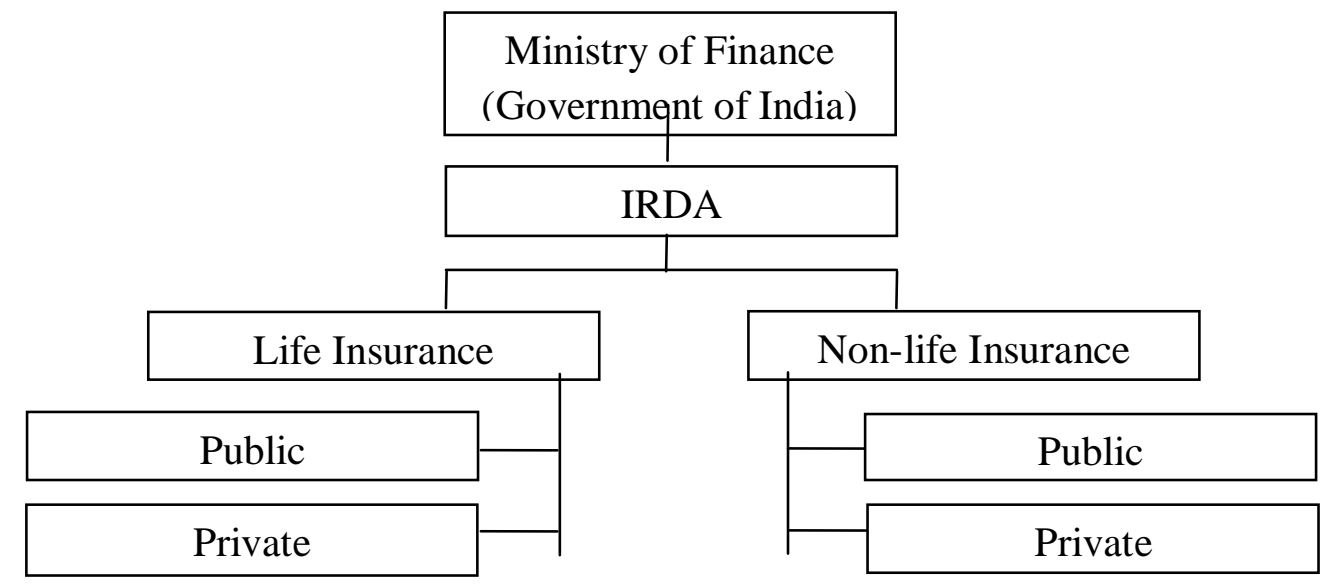

Indian insurance industry structure

Insurance serves a number of valuable economic functions that are largely distinct from other types of financial intermediaries. In order to highlight specifically the unique attributes of insurance, it is worth focusing on those services that are not provided by other financial services providers, excluding for instance the contractual savings features of whole. The indemnification and risk pooling properties of insurance facilitate commercial transactions and the provision of credit by mitigating losses as well as the measurement and management of non diversifiable risk more generally. Typically insurance contracts involve small periodic payments in return for protection against uncertain, but potentially severe losses.

The management of risk is a fundamental aspect of entrepreneurial activity. Entrepreneurs manage the risk of accidental loss by weighing the costs and benefits of each alternative. In a structured risk management process, this involves: (1) identifying the exposures to accidental loss; (2) evaluating alternative techniques for treating each loss exposure; (3) choosing the best alternative; and (4) monitoring the results to refine the choices. Those who do not apply a structured process still make decisions about risk, although sometimes by default rather than design. The scope of an economy's insurance market affects both the range of available alternatives and the quality of information to support decisions.

Insurers also contribute specialized expertise in the identification and measurement of risk. This expertise enables them to accept carefully specified risks at lower prices than non-specialists. They also have an incentive to collect and analyze information about loss exposures, since the more precisely they measure the cost of risk, the more they can expand. As a result, the insurance market generates price signals to the entire economy, helping to allocate resources to more productive uses.

Insurers also have an incentive to control losses, which is a significant social benefit. By offering discounts for seat belts, smoke detectors, or other measures that reduce the frequency or severity of losses, they lower their eventual claims costs, in the process saving lives and reducing injuries. On the investment side, due to the long term nature of their liabilities, sizeable reserves, and predictable premiums, life insurance providers can serve an important function as institutional investors providing capital to infrastructure and other long term investments as well as professional oversight to these investments. Of course, these benefits are fully realized only in markets where insurance providers invest a substantial portion of their portfolios domestically.

The net result of well functioning insurance markets should be better pricing of risk, greater efficiency in the overall allocation of capital and mix of economic activities, and higher productivity. Importantly, these unique functions of insurance should be complementary to banking and financial sector deepening more broadly. For instance, insurance facilitates credit transactions such as the purchase of homes and cars and business operations, while depending in turn on well functioning payment systems and robust investment opportunities. 


\section{Contribution Of Insurance To Growth And Development}

Insurance has had a very positive impact on India's economic development. The sector is gradually increasing its contribution to the country's GDP. In addition, insurance is driving the infrastructure sector by increasing investments each year. Further, insurance has boosted the employment scenario in India by providing direct as well as indirect employment opportunities.

Due to the healthy performance of the Indian economy, the share of life insurance premiums in the gross domestic savings (GDS) of the households sector has increased. The increased contribution of the insurance industry from the household GDS has been ploughed back into the economy, generating higher growth.

\section{Contribution of insurance to infrastructure}

Generally, countries with strong insurance industries have a robust infrastructure and strong capital formation. Insurance generates long-term capital, which is required to build infrastructure projects that have a long gestation period. Concurrently, insurance protects individuals and businesses from sudden unfavorable events. A well developed and evolved insurance sector is needed for economic development as it provides longterm funds for infrastructure development and simultaneously strengthens the risk taking ability.

\section{Contribution of insurance to FDI}

The importance of FDI in the development of a capital deficient country such as India cannot be undermined. This is where the high-growth sectors of an economy play an important role by attracting substantial foreign investments. Currently, the total FDI in the insurance sector, which was INR50.3 billion at the end of FY09, is estimated to increase to approximately INR51 billion in FY10. It is difficult to estimate, but an equal amount of additional foreign investment, can roughly flow into the sector if the government increases the FDI limit from $26 \%$ to $49 \%$.

The insurance sector, by virtue of attracting long-term funds, is best placed to channelize longterm funds toward the productive sectors of the economy. Therefore, the growth in their premium collections is expected to translate into higher investments in other key sectors of the economy. Therefore, the liberalization of FDI norms for insurance would not only benefit the sector, but several other critical sectors of the economy.

\section{Contribution of insurance to employment}

Insurance helps create both direct and indirect employment in the economy. Alongside regular jobs in insurance, there is always demand for a range of associated professionals such as brokers, insurance advisors, agents, underwriters, claims managers and actuaries.

The increasing insurance business has increased the demand for highly skilled professionals as well as semiskilled and unskilled people.

\section{Insurance Contributes Positively to Economic Growth}

The deepening of insurance markets makes a positive contribution to economic growth. While life insurance is causally linked to growth only in higher income economies, nonlife insurance makes a positive contribution in both developing and higher income economies. Some research suggests that the positive contribution of life insurance to growth is primarily through the channel of financial intermediation and long term investments. However, it is important to note that these studies do not address the important contributions to individual and social welfare from risk management.

\section{Strong Complementarities between Insurance and Banking}

Insurance and banking system deepening appear to play complementary roles in the growth process. Although insurance and banking separately each make positive contributions to growth, their individual contributions are greater when both are present. There is also some evidence that the development of insurance markets contributes to the health of securities markets.

\section{Micro - Insurance}

The contribution of insurance to an economy's growth and efficiency is not the only entry point into its role in development. The contribution of insurance to poverty alleviation and the welfare of the poor is also potentially of considerable importance, although the quantitative evidence on this point is not on very firm grounding. Nonetheless, case studies and other qualitative evidence make a persuasive case that the potential social value of so-called micro-insurance provision to poor households and small-scale entrepreneurs warrants a great deal more experimentation with business models and products to develop scaleable approaches that combine commercial and philanthropic elements. 
As noted above, patterns of insurance coverage suggest a positive correlation with income - at least up to a point where the value of insurance begins to diminish relative to the value of overall household assets. But this does not tell us anything about the potential social value of insurance provision at lower levels of income only that poor consumers either do not or cannot purchase insurance at currently prevailing prices and availability.

In the absence of risk pooling mechanisms, plunges in incomes due to death, disability, and adverse agricultural outcomes often translate into substantial decreases in consumption and investment that can permanently set back a poor family's livelihoods and prospects. When drought or floods lead to low agricultural yields, critical health interventions may be delayed, education of younger members of a household put on hold indefinitely, and land, livestock or equipment permanently forfeited.

Due to the catastrophic consequence of such losses, there is extensive evidence that in the absence of formal insurance poor households and communities attempt to 'self-insure' through a combination of building assets and diversifying sources of income. The result most likely is investment in a set of lower risk but also lower return activities - and even this degree of self-insurance is highly incomplete.

There are also a variety of mechanisms that have emerged at the community level, such as community pooling of informal insurance contributions to cover burial costs. Community-based insurance mechanisms surmount the problems of transactions costs and lack of legally enforceable contracts through personal relationships and piggybacking on traditional small-scale financial collection mechanisms, similar to the early stages of micro-credit. However, they offer only feeble protection in the face of community-wide, covariate shocks, since they do not typically pool risk across broader populations and are limited in the types of products they can provide.

For micro entrepreneurs and farmers, the net result can be a significant drag on overall economic performance as they choose to invest in activities that might offer the best risk-return profile from an individual point of view but are suboptimal from an economy-wide point of view where a higher returning but riskier set of investments might lead to better aggregate outcomes.

High transactions costs are the main impediment standing in the way of a systematic shift from informal to formal mechanisms for managing and pooling risk for poorer households and small entrepreneurs. As such, the emerging field of micro-insurance faces many of the same challenges faced by micro-credit two decades ago in developing creative mechanisms for reducing or subsidizing transactions costs. Indeed, microcredit institutions are among the first to venture into micro-insurance products, and their most popular initial insurance product offering was 'credit-life' insurance to pay off any debts associated with outstanding microcredit loans in the event of death. As this field expands, it might follow a trajectory similar to that of microfinance, perhaps starting with NGO providers funded on a philanthropic basis, but rapidly expanding to include commercial partners as financial intermediaries as scaleable business models emerge.

In parallel, in some countries the public sector is taking a greater interest in the provision of social insurance to poorer populations - through subsidized public insurance schemes for health, natural disasters, or weather-related crop insurance. Government mandates for compulsory insurance also expand the covered population although the difficulty of achieving risk-based pricing can lead to market distortions.

\section{1: Household Insurance -}

Micro-finance providers and other community-based financial intermediaries have begun to diversify into insurance products. In Uganda, 2 million people have purchased life insurance bundled with savings and micro-credit. Burial insurance is growing rapidly in other areas, and there are some experiments with property insurance such as for livestock and dwellings.

\section{2: Natural Disasters, Weather, and Crop Insurance}

There should be enormous potential for natural disaster and weather insurance to improve the performance of lower income economies, which tend to be more vulnerable to high volatility in incomes due to commodity price fluctuations and natural disasters due to poor building codes and infrastructure. Current investments in new products and innovations in weather and natural disaster insurance should be followed closely, as it is anticipated that climate change will exacerbate the incidence of weather patterns and natural disasters in many poor areas.

In recent years, the World Bank and other donors have been involved in experiments in countries such as Turkey and Mexico that provide earthquake risk insurance financed through a combination of reinsurance and the capital markets. In areas of Asia and Africa, there is growing interest in weather derivatives to insure against weather-associated agricultural losses. These are designed to sidestep the traditional incentive (moral hazard) problems associated with crop insurance by using independent measurements of weather outcomes such as rainfall rather than crop yields. 


\section{3: Health Insurance}

As with the wealthier economies, the development of health insurance markets in developing economies depends on the composition of health delivery providers - whether private or public - and the government's involvement in health insurance provision. However, there is a strong tendency in poorer economies for households to bear responsibility for paying a much higher proportion of overall health costs out of pocket than in richer economies, which leads to underinvestment in health services (particularly on the preventive side) and vulnerability to health related consumption shocks.

Thus, a strong case can be made for improving health outcomes in poor countries through a varied combination of public and private insurance provision depending on the institutional setting. Indeed, countries such as Mexico and Colombia have undertaken interesting reforms in this area in recent years, and this is likely to be an area of strong growth.

\section{4: Small-Scale Entrepreneurs}

The economic contribution of small enterprises to middle- and high-income economies is well-known. However, in many poor economies, start-ups and small-scale enterprise fall short of their potential due to a variety of barriers, including access to capital. As attention to these barriers grows, it is critical to put insurance high on the list. While the risk appetite of large corporations can be debated, small scale entrepreneurs whose household wealth is tied up in their business enterprises are undoubtedly preoccupied with managing risk.

In the absence of risk management tools provided by formal insurance, there will be a tendency to under invest in higher risk, higher return activities, thus diminishing the potential contribution of the critical small and medium sized enterprise sector to employment, investment, and growth overall.

In sum, extending accessible insurance products to poor households and small scale entrepreneurs should be a core part of the agenda of democratizing access to financial assets. When successful programs are taken to scale, it will not only add measurably to social welfare but also hold the promise of generating a more productive and higher growth mix of activities and investments - with a payoff perhaps greater than microcredit.

\section{Insurance and Indian Budget 2011-2012}

A. Budget proposes to move the following legislations in the financial sector: (i) The Insurance Laws (Amendment) Bill, 2008;

(ii) The Life Insurance Corporation (Amendment) Bill, 2009;

(iii) The revised Pension Fund Regulatory and Development Authority Bill, first introduced in 2005;

B. Services provided by life insurance companies in the area of investment are also proposed to be brought into tax net on the same lines as ULIPs.

C. Budget also proposes to extend the Rashtriya Swasthya Bima Yojana - a health insurance for the poor - to cover workers of the unorganized sector like hazardous mining and associated industries like slate and slate pencil, dolomite, mica and asbestos.

\section{Analysis}

The insurance legislation would increase the FDI limit to 49 percent from the current 26 percent The LIC bill would increase the share capital of Life Insurance Corporation (LIC) to Rs. 100 crore from its current Rs. 5 crore.

The PFRDA Bill would bring in a full-fledged regulator for the pension sector. Now it is regulated by an interim authority.

Insurance bill will empower IRDA (Insurance Regulatory and Development Authority) to introduce forwardlooking regulations to promote sustainable growth of the industry. The bill gives a lot of flexibility to the IRDA in framing regulations.

Due to the modification proposed in budget for service tax on fund management charges, some guaranteed unit linked insurance policies (ULIPs) will attract higher charges.

A very senior citizen category has been introduced at the age of 80 years and above with exemption limit of Rs.500,000. Also increase in income tax exemption limit to Rs.250,000. For senior citizens and the reduction in the age limit for senior citizens to 60 years will help seniors to enjoy pension in the retirement years without tax impact.

NOTE:The bills relating to the insurance sector has been pending for past several years.

- The Insurance Laws (Amendment) Bill, 2008 was introduced in the Rajya Sabha in December 2008 and was referred to the Standing Committee on Finance in September 2009.

- The committee is yet to submit its report. 
- $\quad$ Life Insurance Corporation (Amendment) Bill, 2009 was introduced in the Lok Sabha in July 2009 and was referred to the Standing Committee on Finance, which submitted its report in March 2010.

- Pension Fund Regulatory and Development Authority Bill was first introduced in 2005 It lapsed with the dissolution of the 14th Lok Sabha

- Insurance reforms in 2011-12 mainly depend on how soon the government is able to get insurance related bills introduced \& passed. .

\section{Role of Insurance Regulatory and Development Authority in Indian Insurance Sector}

The Insurance Regulatory and Development Authority Act of 1999 brought about several crucial policy changes in the insurance sector of India. It led to the formation of the Insurance Regulatory and Development Authority (IRDA) in 2000.

The goals of the IRDA are to safeguard the interests of insurance policyholders, as well as to initiate different policy measures to help sustain growth in the Indian insurance sector.

The Authority has notified 27 Regulations on various issues which include Registration of Insurers, Regulation on insurance agents, Solvency Margin, Re-insurance, Obligation of Insurers to Rural and Social sector, Investment and Accounting Procedure, Protection of policy holders' interest etc. Applications were invited by the Authority with effect from 15th August, 2000 for issue of the Certificate of Registration to both life and non-life insurers. The Authority has its Head Quarter at Hyderabad. Detailed information on IRDA is available at their web-site www.irdaindia.org

IRDA has the responsibility of protecting the interest of insurance policyholders. Towards achieving this objective, the Authority has taken the following steps:

- IRDA has notified Protection of Policyholders Interest Regulations 2001 to provide for: policy proposal documents in easily understandable language; claims procedure in both life and non-life; setting up of grievance redressal machinery; speedy settlement of claims; and policyholders' servicing. The Regulation also provides for payment of interest by insurers for the delay in settlement of claim.

- The insurers are required to maintain solvency margins so that they are in a position to meet their obligations towards policyholders with regard to payment of claims.

- It is obligatory on the part of the insurance companies to disclose clearly the benefits, terms and conditions under the policy. The advertisements issued by the insurers should not mislead the insuring public.

- All insurers are required to set up proper grievance redress machinery in their head office and at their other offices.

- The Authority takes up with the insurers any complaint received from the policyholders in connection with services provided by them under the insurance contract.

\section{Growth of New Policies}

The IRDA in insurance industry in India has taken impressive measures in recent years and has recorded phenomenal growth complemented by country's improving economic growth. The Indian insurance is gaining in size and is in par with the Asian markets. The business of insurance is related to the protection of the economic values of assets of the policy holders. The number of new policies issued by the life insurer in accordance with IRDA is an index of growth of life insurer. The IRDA is looking at making insurance policies more investor-friendly by introducing tax exemption on insurance policies. Whole IRDA is still considering a proposal by LIC to link tax relief to the term of the life insurance policy, reports suggest IRDA has backed a move to introduce separate tax exemption limit on life insurance policies.

\section{Conclusion}

The growth of the Indian economy has been diminishing due to various reasons, but the Indian growth story is still alive as Indians has a habit of moving slowly but steadily and in the end we win the race. Currently the situations are not in our favour but as soon the above problems settles down, we may back on track. At the same time many sectors are supporting to the growth of the Indian economy, among that insurance sector's contribution is very high. The growth performance of the insurance industry has increased tremendously since the establishment of IRDA in India, which supervise and controlled the entire insurance industry. The increase in number of insurer both in life and non-life, growth in insurance penetration and density, increase in number of policies issued and increase in the speed of claims settlement and the in many more aspects the IRDA is playing a prominent role in the Indian insurance sector

[1] Insurance Regulatory and development authority (IRDA)

[2] Life Insurance Council

[3] General Insurance Council

[4] Centre for monitoring Indian Economy

[5] Sinha, Tapen. 2001, "The role of financial intermediation in economic growth,"

[6] Sinha, Tapen. 2004a, "Relationship between Economic Growth and Saving: Evidence from India,"

[7] Indian Economy Atlantic Publishers and Distributors - New Delhi

[8] Indian Economy, K.P.M Sundharam, Gaurav Datt, Ashwani Mahajan - S. Chand Publisher 66thRevised Edition

[9] Understanding the Problems of Indian Economy/Uma Kapila. Sixth edition. New Delhi, Academic Foundation, 2005, 